\title{
$\square$
}

\section{Economic Freedom and Employment Growth in U.S. States}

\author{
Thomas A. Garrett and Russell M. Rhine
}

\begin{abstract}
The authors extend earlier models of economic growth and development by exploring the effect of economic freedom on U.S. state employment growth. They find that states with greater economic freedom-defined as the protection of private property and private markets operating with minimal government interference-experienced greater rates of employment growth. In addition, they find that less-restrictive state and national government labor market policies have the greatest impact on employment growth in U.S. states. Beyond labor market policies, state employment growth is influenced by state and local government policies, but not the policies of all levels of government, including the national government. Their results suggest that policymakers concerned with employment should seriously consider the degree to which their own labor market policies and those of the national government may be limiting economic growth and development in their respective states. (JEL H70, O20, O51, R58)
\end{abstract}

Federal Reserve Bank of St. Louis Review, January/February 2011, 93(1), pp. 1-18.

arge differences exist in the economic growth and development of countries around the world. An extensive literature finds numerous factors that, taken together, explain why certain countries experience greater rates of income and employment growth than others. The most-cited factors contributing to economic growth include the stock of human capital, investment in technology, trade specialization and foreign direct investment, and low levels of political corruption. ${ }^{1}$ In addition to these factors, a more recent literature has explored the role of economic and political institutions in the economic growth of countries. Studies have shown that countries with greater economic freedom-meaning the protection of

1 See Barro $(1997,2001)$ and Barro and Sala-i-Martin (2004) for a review of the literature on cross-country economic growth. See also Billger and Goel (2009), Chatterjee and Turnovsky (2007), and Blankenau and Simpson (2004). private property and private markets operating with minimal government interference-have greater rates of economic growth than countries with lower levels of economic freedom (Cole, 2003; Sturm and De Haan, 2001; Powell, 2003; Gwartney, 2009).2

Differences in economic growth (as measured by income and employment) also exist across subnational jurisdictions (e.g., states, provinces). For example, average annual employment growth in the United States from 1960 to 2008 was nearly 2 percent, but employment growth in individual states was much different-ranging from 0.8 percent in New York to nearly 5.5 percent in Nevada.

\footnotetext{
2 In Economic Freedom of the World, Gwartney and Lawson (2009) derive a single economic freedom index number for each country that places each country on a continuum from 0 to 10 , where 10 represents the highest degree of reliance on free-market capitalism. The index considers five categories: the size of government, property rights and the legal system, trade freedom, sound money, and minimal regulation.
}

Thomas A. Garrett is an assistant vice president and economist at the Federal Reserve Bank of St. Louis. Russell M. Rhine is an associate professor of economics at St. Mary's College of Maryland.

(C) 2011, The Federal Reserve Bank of St. Louis. The views expressed in this article are those of the author(s) and do not necessarily reflect the views of the Federal Reserve System, the Board of Governors, or the regional Federal Reserve Banks. Articles may be reprinted, reproduced, published, distributed, displayed, and transmitted in their entirety if copyright notice, author name(s), and full citation are included. Abstracts, synopses, and other derivative works may be made only with prior written permission of the Federal Reserve Bank of St. Louis. 


\section{Garrett and Rhine}

In addition, the average annual per capita income growth for the 10 Canadian provinces from 1981 to 2008 was 4.3 percent, but the growth rates for individual provinces ranged from a low of 3.8 percent in British Columbia to a high of 5.3 percent in Newfoundland and Labrador. ${ }^{3}$

Many factors that explain differences in crosscountry growth also explain differences in state economic growth. Crain and Lee (1999) and Garrett, Wagner, and Wheelock (2007) have shown that income growth is higher in U.S. states with greater industrial diversity, a greater percentage of the population with a college degree, a greater percentage of the population in the labor force, and state government as a smaller share of gross state product (GSP). Tomljanovich (2004) demonstrated that higher state tax rates reduce state economic growth (measured by per capita GSP) for several years following a tax increase. ${ }^{4}$ Similarly, Nickell, Nunziata, and Ochel (2005) and Daveri and Tabellini (2000) found that higher labor taxes reduced employment. Finally, Quan and Beck (1987) and Nistor (2009) found that states and counties with greater human capital investment (i.e., education) had lower unemployment rates and greater employment growth.

It is reasonable that differences in economic freedom across states may explain variation in the growth of U.S. states as well. Economic and political institutions, such as business regulation, taxation, and government spending, differ across state governments just as they do across national governments. To date, however, empirical models of state economic growth have essentially ignored the potential role of state economic and political institutions in state-level economic growth.

In this paper, we augment prior models of state economic growth by examining the effect of economic freedom on U.S. state employment growth. We use the state-level economic freedom indices in Karabegovic and McMahon's (2008) Economic Freedom of North America 2008. ${ }^{5}$

\footnotetext{
3 U.S. employment data are from the Bureau of Labor Statistics. Canadian data are from Statistics Canada.

4 See also Dye (1980) and Wasylenko and McGuire (1985).

5 Economic Freedom of North America 2008 can be accessed at www.freetheworld.com/efna.html.
}

The overall index, described in more detail later, considers three areas of state-level economic freedom-the size of government, taxation, and labor market freedom. In essence, the economic freedom indices measure the size of governments, defined very broadly. The paper's testable hypothesis is that states with greater economic freedom (i.e., smaller government, less taxation, and more labor market freedom) have higher rates of employment growth. More economic freedom in a state can lead to greater employment growth through two channels: (i) by encouraging higher levels of entrepreneurial activity and smallbusiness creation (Kreft and Sobel, 2005) and (ii) by reducing the costs, both financial and regulatory, on existing businesses in the state (Karabegovic and McMahon, 2008).

We conduct several empirical exercises using different measures of economic freedom. It is reasonable to believe that the three areas of economic freedom do not exert equal influences on state employment growth. This belief is motivated by the fact that each area of economic freedom has a different impact on other state-level economic variables, such as entrepreneurship and income inequality (Kreft and Sobel, 2005, and Ashby and Sobel, 2008). Thus, we not only test for the effect of aggregate economic freedom in our employment growth models, but we also consider how each of the three areas of aggregate economic freedom influences state employment growth. This provides an opportunity to determine which economic and political factors (the size of government, taxation, or labor market freedom) have the greatest impact on state employment growth.

Because federal economic policies (e.g., minimum wage legislation, federal personal and corporate income taxes, federal government transfers to states) influence the economic and political climate in individual states, our empirical models consider state-level economic freedom indices based on state and local government policies, as well as economic freedom indices for national, state, and local government policies. This allows us to determine which level(s) of government policy have the greatest impact on state employment growth. 
Our results indicate that economic freedom is a significant factor in state employment growth in addition to the more traditional determinants of growth, such as industrial diversity and human capital. We find that the effect of economic freedom on state employment growth varies depending on the period studied and which economic freedom index is used. Differences are found when we consider (i) each of the three areas of economic freedom individually and (ii) economic freedom based on state government policies versus state and national government policies. The results have important policy implications for all those concerned with subnational economic growth and development.

\section{ECONOMIC FREEDOM IN U.S. STATES}

The state-level economic freedom indices used here are from Economic Freedom of North America 2008 (Karabegovic and McMahon, 2008). The indices are "an attempt to gauge the extent of the restrictions on economic freedom imposed by governments in North America" (Karabegovic and McMahon, 2008, p. 3). The underlying intuition for the indices is that once state governments reach a certain size in terms of taxation, spending, and regulation, additional government intervention in the private sector reduces economic growth. One conjecture in the literature is that the optimal size of each state government in terms of maximizing private sector economic growth (through government spending on infrastructure, eliminating externalities, and so on) is less than the current size of state and local governments (Mitchell, 2005). Thus, if the conjecture is true, it is expected that, on the margin, states with relatively greater government intrusion in the private sector (i.e., those with lower economic freedom indices) will experience lower economic growth.

The economic freedom indices are constructed on a 10-point scale, with a higher value denoting greater economic freedom. Economic freedom is evaluated using two levels of government-the subnational level (state and local governments) and the "total" government level (national, state, and local governments). ${ }^{6}$ Overall freedom indices for the two levels of government are each based on three areas of government intervention: the size of government (Area 1), takings and discriminatory taxation (Area 2), and labor market freedom (Area 3). ${ }^{7}$ A higher index for each of the three areas implies a smaller state government, less taxation, and greater labor market freedom, respectively. Each area has its own economic freedom index, and the overall index is an equally weighted average of the three areas. The indices are constructed using data on each of the components (Table 1), and each economic freedom index for a particular state is relative to that of all other states by construction. ${ }^{8}$

Figure 1 illustrates the variation in overall economic freedom (subnational level) across the continental U.S. states for 2005. Economic freedom ranged from a low of 5.5 in West Virginia to a high of 8.3 in Delaware, with an average value of 6.9. States in the Southeast and the Midwest tend to have a higher level of economic freedom than states on the West Coast and in the Northeast. Although not shown here, the level of economic freedom in each state is similar in proximal years, but large differences do exist in the level of economic freedom in a state over time. ${ }^{9}$

The primary advantage of the economic freedom index is that it provides a concise, summary measure of government restrictions on free-market activity. ${ }^{10}$ As a result, not only have dozens of

6 Although not used in this paper, provincial economic freedom indices are available for the Canadian provinces; see Karabegovic and McMahon (2008).

7 "Discriminatory taxation" means the taxing of only those individuals engaging in a particular activity (e.g., sales taxes are paid only by those who make taxable retail purchases). The term "takings" refers to the revenue to governments acquired through taxation. The average correlation among the three areas of state-level economic freedom is 0.51 .

8 See Karabegovic and McMahon (2008, pp. 77-80) for a discussion of how the economic freedom indices are calculated.

9 Annual state-level economic freedom indices from 1980 to 2005 are available at the website of the Economic Freedom Network (www.freetheworld.com/efna.html).

${ }^{10}$ An econometric advantage of using the economic freedom index in empirical modeling rather than the set of variables in Table 1 is that many of the latter are highly correlated, thus likely decreasing the precision of the coefficient estimates. The use of a single measure of economic freedom eliminates this potential problem. 
Figure 1

Economic Freedom in U.S. States (2000)

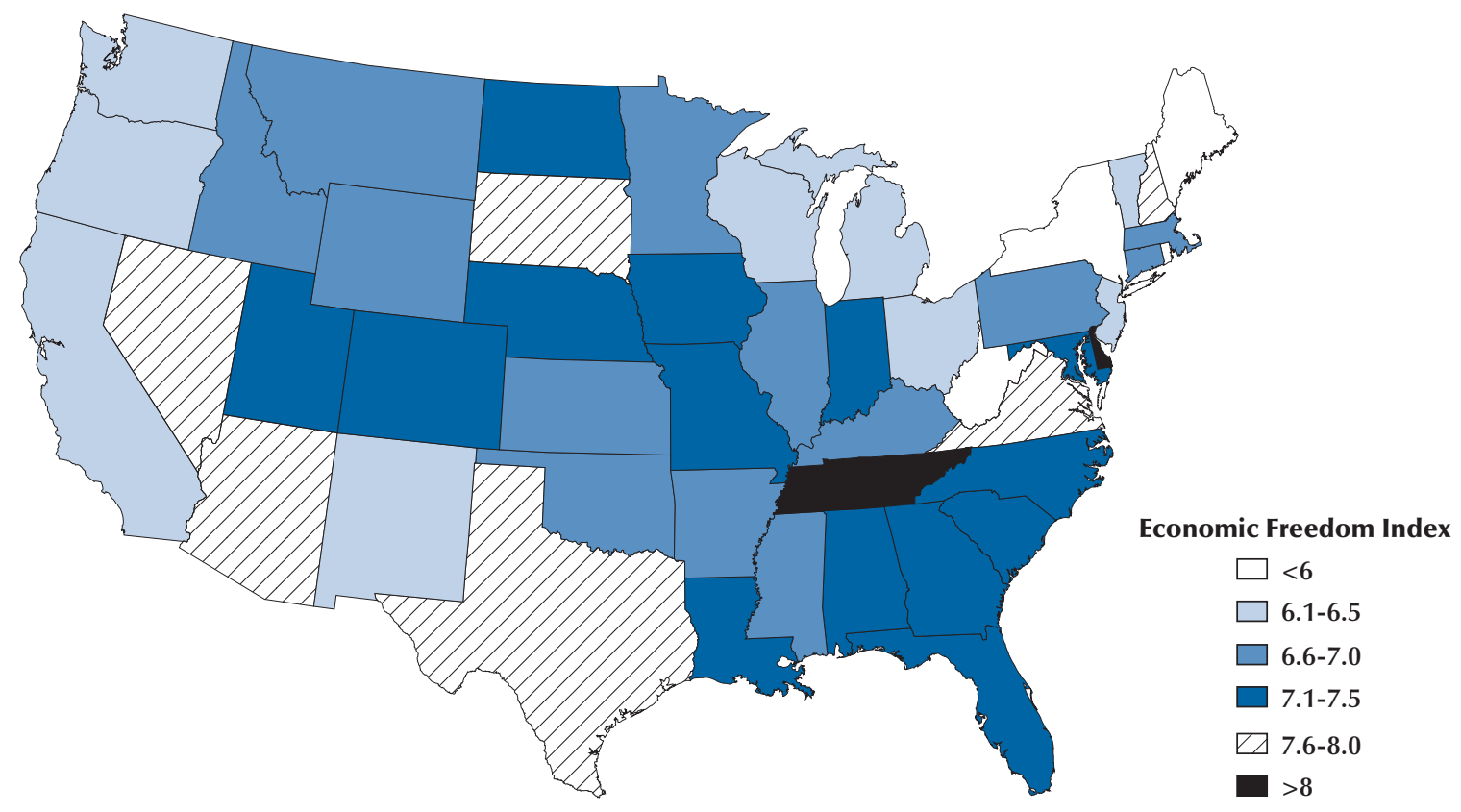

\section{Table 1}

\section{Areas and Components of State-Level Economic Freedom}

\section{Area}

Component

\section{Area 1: Size of government}

$1 \mathrm{~A}$

$1 \mathrm{~B}$

$1 \mathrm{C}$
General consumption expenditures by government as a percentage of GDP

Transfers and subsidies as a percentage of GDP

Social Security payments as a percentage of GDP

\section{Area 2: Takings and discriminatory taxation}

$2 A$
$2 B$
$2 C$
$2 D$

Total tax revenue as a percentage of GDP

Top marginal income tax rate and the income threshold at which it applies Indirect tax revenue as a percentage of GDP

Area 3: Labor market freedom
$3 \mathrm{~A}$
Minimum wage legislation
3B
Government employment as a percentage of total employment
$3 \mathrm{C}$
Union density

SOURCE: Karabegovic and McMahon (2008). 
studies explored the impact of economic freedom on various measures of economic growth, but additional studies also have explored how the economic freedom index correlates with other variables, such as health (Norton, 1998, and Esposto and Zaleski, 1999), migration (Melkumian, 2004), income inequality (Ashby and Sobel, 2008), the productivity of investment (Dawson, 1998), and entrepreneurship (Ovaska and Sobel, 2005, and Kreft and Sobel, 2005).

Although the economic freedom index has been used in many studies, it is not without critics (Hanson, 2003). One criticism is that the index, because it is a summary measure, is less precise in measuring economic freedom than many of the component variables used to create the index, thus generating bias in empirical models. One way to mitigate this problem (as we do here) is to estimate regression models using the economic freedom index for each area (see Table 1) in addition to the overall freedom index (Heckelman, 2005). A second criticism is the simultaneity (both in levels and in growth rates) between the economic freedom index and economic outcomes such as gross domestic product (GDP) and income. ${ }^{11}$ Studies have regressed future growth on the contemporaneous economic freedom index to minimize this problem, which is the methodology we follow here. A final criticism of the economic freedom index is that it entails ideological bias because the index is created by a free-market organization-the Fraser Institute. Ashby and Sobel (2008) argue, however, that even if an ideological bias exists, this bias actually ensures that the index does capture the desired measurements.

Despite some controversy surrounding the economic freedom index, we assume that the index approach is valid. We leave it to future research to determine whether the index is an appropriate gauge of economic freedom. As discussed in the following section, we design our empirical models to ensure that the potential econometric problems of the economic freedom index-specification bias and simultaneityare taken into account.

\footnotetext{
${ }^{11}$ If economic freedom is a normal good, then wealthier countries would demand more economic freedom.
}

\section{DATA AND EMPIRICAL METHODOLOGY}

We estimate our models of state employment growth for three separate periods (1980-90, 19902000, and 2000-05) using data for the 50 U.S. states. ${ }^{12}$ We perform the analysis for the three periods to assess the temporal robustness of the relationship, if any, between economic freedom and state employment growth. ${ }^{13}$ We run several empirical specifications, each of which considers one of the several economic freedom indices discussed earlier-the overall index, the index for each of the three areas (see Table 1), and the indices for subnational government (state and local) policies and total government (national, state, and local) policies.

Our empirical models are designed to examine the degree to which differences in economic freedom across states in the initial year of each 10- and 5-year period can explain differences in state employment growth over the period. ${ }^{14}$ Two reasons exist for choosing this framework. First, regressing future employment growth on an initial value of the economic freedom index minimizes any simultaneity and endogeneity between the economic freedom index and state employment growth that exists over time (Heckelman, 2005). Second, a time lag exists between when government policies are implemented and when their effects are known or realized, so it is reasonable

\footnotetext{
${ }^{12}$ We end the analysis in 2005, the latest year for which economic freedom data were available at the time of writing.

${ }^{13}$ The economic freedom index is not available before 1981. Thus, our models of employment growth over the 1980-90 period use the economic freedom index for 1981.

${ }^{14}$ Our empirical specification is similar to that used in the convergence literature. Implicit in the empirical specification is the idea that each economy has a steady-state growth path that follows a time trend. Quah (1993) provides cross-country evidence on income growth that refutes this assumption. Durlauf (2001) raises other potential problems, such as nonlinearities, a disconnect between growth theory and empirical modeling (i.e., which variables should be included in growth models and the potential problem of simultaneity), and, finally, heterogeneous parameters. We argue that differences across states in terms of heterogeneous parameters and growth paths are likely to be significantly less than differences across countries because political systems and components of government revenue and spending are much more similar across states than across countries.
} 


\section{Garrett and Rhine}

to model future employment growth as a function of past government policies. ${ }^{15}$

Although there is little disagreement that fiscal policy and government regulation work with lags, we have no a priori hypothesis as to the exact lag to consider in our empirical models. Previous studies have considered lags ranging from several years to several decades. To ensure consistency with many previous studies, we chose to explore the effect of economic freedom on state employment growth over two 10-year periods and one 5-year period. Our results are, of course, specific to the starting years chosen and the length of time for which we specify employment growth.

Previous studies on state economic growth serve as a guide for the variables to include in our models. Of the dozen or so variables we could have included, we chose those that were significant determinants of economic growth in earlier studies. To alleviate likely simultaneity between state employment growth and each of the independent variables, some variables in our models (described below) are specified as growth rates, whereas the levels of other variables are included for the initial year of the study period (1980, 1990, or 2000). ${ }^{16}$

We account for the human capital of a state by including the percentage change in the share of the state's population older than 25 years of age that has obtained a bachelor's degree or higher (Quan and Beck, 1987, and Nistor, 2009). ${ }^{17}$ Our expectation is that states with greater growth in the share of the population with a college degree will have higher rates of employment growth.

State population density (persons per square mile) for the initial year is included to capture the effects of agglomeration on state economic

\footnotetext{
15 See Auerbach and Gale (2009).

${ }^{16}$ We considered several variables in addition to the variables used in the final empirical models. Specifically, we considered human capital spending, the share of a state's population between 18 and 64 years of age, and the measure of industrial diversity suggested by Crain and Lee (1999). We considered these variables in levels and in percent changes. The coefficients of these variables were statistically insignificant in most regression specifications, and there was little change in the size and sign of the remaining coefficients. We thus chose to drop these variables from our final specifications.

${ }^{17}$ Data are from the U.S. Census.
}

growth. Haughwout (1999), Blumenthal, Wolman, and Hill (2009), and Puga (2010) have demonstrated that areas with greater agglomeration experience higher growth rates. ${ }^{18}$ Assuming a concave path for state economic growth as suggested by the convergence literature (Carlino and Mills, 1996, and Webber, White, and Allen, 2005), we expected that states with greater population density in the initial year would have lower rates of future employment growth.

For the initial year of each study period we include employment for the manufacturing and service sectors to control for industry mix. Each type of employment is expressed as a percentage of total employment (Nichol, 2009). ${ }^{19}$ The expected sign of each variable is unclear. Generally, the manufacturing sector's share of total employment in U.S. states has been declining, whereas the service sector's share has increased. States with a greater share of employment in manufacturing in the initial year may have experienced slower total employment growth if employment growth in other sectors, including service sectors, was insufficient to offset any decline in manufacturing. Similarly, states with a greater share of employment in services in the initial year may have experienced greater employment growth if service sector growth offset declining growth in other sectors. In short, the sign of each variable depends on the relative size of each sector in the initial year and the employment dynamics in all other sectors (Elhorst, 2003).

Descriptive statistics for the variables used in the analysis are shown in Table 2. A few comments regarding the data are noteworthy. Employment growth across the states averaged 21 to 23 percent for the 1980s and 1990s and 2.5 percent in the early 2000s. Overall economic freedom averaged slightly above 7.0 in each of the three years. Economic freedom in Areas 1 and 2 (except for the 1990-2000 period) decreased over time, whereas economic freedom for Area 3 increased over time. The standard deviations (SDs) of the

\footnotetext{
${ }^{18}$ State population and area data were obtained from the U.S. Census.

${ }^{19}$ Employment share data were calculated using industry employment data from the Bureau of Economic Analysis.
} 


\section{Table 2}

\section{Descriptive Statistics}

\begin{tabular}{|c|c|c|}
\hline Variable & Mean & SD \\
\hline Percent change in employment ${ }_{1980-1990}$ & 21.53 & 12.62 \\
\hline Percent change in employment ${ }_{1990-2000}$ & 23.20 & 12.09 \\
\hline Percent change in employment $2000-2005$ & 2.56 & 4.63 \\
\hline Economic freedom $_{1981}$ & 7.052 & 0.942 \\
\hline Economic freedom $_{1990}$ & 7.060 & 0.688 \\
\hline Economic freedom $_{2000}$ & 7.010 & 0.692 \\
\hline Economic freedom $_{1981}$ (Area 1) & 7.702 & 0.988 \\
\hline Economic freedom $_{1990}$ (Area 1) & 7.616 & 0.800 \\
\hline Economic freedom $_{2000}$ (Area 1) & 7.330 & 0.938 \\
\hline Economic freedom $_{1981}$ (Area 2) & 7.228 & 1.036 \\
\hline Economic freedom $_{1990}$ (Area 2) & 6.938 & 0.739 \\
\hline Economic freedom $_{2000}$ (Area 2) & 6.988 & 0.786 \\
\hline Economic freedom $_{1981}$ (Area 3) & 6.220 & 1.161 \\
\hline Economic freedom $_{1990}$ (Area 3) & 6.638 & 0.907 \\
\hline Economic freedom $_{2000}$ (Area 3) & 6.742 & 0.811 \\
\hline Percent change in bachelor's degree ${ }_{1980-1990}$ & 22.87 & 7.52 \\
\hline Percent change in bachelor's degree ${ }_{1990-2000}$ & 20.65 & 4.35 \\
\hline Percent change in bachelor's degree ${ }_{2000-2005}$ & 10.91 & 2.73 \\
\hline Population density ${ }_{1980}$ & 154.87 & 222.60 \\
\hline Population density ${ }_{1990}$ & 166.19 & 235.35 \\
\hline Population density 2000 & 181.90 & 250.15 \\
\hline Percent in services $_{1980}$ & 27.30 & 4.47 \\
\hline Percent in services $_{1990}$ & 34.48 & 4.66 \\
\hline Percent in services $_{2000}$ & 38.98 & 4.56 \\
\hline Percent in manufacturing ${ }_{1980}$ & 21.24 & 8.27 \\
\hline Percent in manufacturing ${ }_{1990}$ & 15.68 & 5.85 \\
\hline Percent in manufacturing ${ }_{2000}$ & 13.06 & 4.83 \\
\hline
\end{tabular}

NOTE: The sample size is 50 for 1980, 1990, and 2000. The economic freedom index is for the state and local government level. Area 1 , size of government; Area 2, takings and discriminatory taxation; Area 3, labor market freedom. See text for further description of the economic freedom indices. 
Table 3

State and Local Economic Freedom and State Employment Growth (1980-90)

\begin{tabular}{|c|c|c|c|c|}
\hline \multirow[b]{2}{*}{ Variable } & \multicolumn{4}{|c|}{$\begin{array}{l}\text { Dependent variable: } \\
\text { Percent change in state payroll employment (1980-90) }\end{array}$} \\
\hline & (1) & (2) & (3) & (4) \\
\hline Economic freedom $_{1981}$ & $\begin{array}{l}3.768^{*} \\
(1.72)\end{array}$ & & & \\
\hline Economic freedom $_{1981}$ (Area 1) & & $\begin{array}{l}5.684^{* *} \\
(3.23)\end{array}$ & & \\
\hline Economic freedom $_{1981}$ (Area 2) & & & $\begin{array}{r}0.953 \\
(0.53)\end{array}$ & \\
\hline Economic freedom $_{1981}$ (Area 3) & & & & $\begin{array}{r}2.754 \\
(1.30)\end{array}$ \\
\hline Percent $\Delta$ in bachelor's degree & $\begin{array}{r}0.529 \\
(0.95)\end{array}$ & $\begin{array}{r}0.536 \\
(1.10)\end{array}$ & $\begin{array}{r}0.471 \\
(0.80)\end{array}$ & $\begin{array}{c}0.648 \\
(1.11)\end{array}$ \\
\hline Population density ${ }_{1980}$ & $\begin{array}{l}-0.018^{* *} \\
(2.27)\end{array}$ & $\begin{array}{l}-0.016^{* *} \\
(2.12)\end{array}$ & $\begin{array}{l}-0.019 * * \\
(2.24)\end{array}$ & $\begin{array}{l}-0.020^{* *} \\
(2.41)\end{array}$ \\
\hline Percent in services $_{1980}$ & $\begin{array}{l}1.482^{* *} \\
(3.04)\end{array}$ & $\begin{array}{l}1.638^{* *} \\
(3.67)\end{array}$ & $\begin{array}{l}1.446^{* *} \\
(2.74)\end{array}$ & $\begin{array}{l}1.399 * * \\
(2.79)\end{array}$ \\
\hline Percent in manufacturing ${ }_{1980}$ & $\begin{array}{c}0.406 \\
(1.10)\end{array}$ & $\begin{array}{c}0.589^{*} \\
(1.78)\end{array}$ & $\begin{array}{c}0.373 \\
(0.98)\end{array}$ & $\begin{array}{c}0.275 \\
(0.70)\end{array}$ \\
\hline Constant & $\begin{array}{c}-50.149^{* *} \\
(1.99)\end{array}$ & $\begin{array}{c}-75.600^{* *} \\
(3.23)\end{array}$ & $\begin{array}{c}-29.471 \\
(1.10)\end{array}$ & $\begin{array}{c}-37.726 \\
(1.39)\end{array}$ \\
\hline Regional dummy variables & Yes & Yes & Yes & Yes \\
\hline Adjusted $R^{2}$ & 0.274 & 0.339 & 0.225 & 0.263 \\
\hline Adjusted $R^{2}$ (omit Freedom Index) & 0.240 & 0.240 & 0.240 & 0.240 \\
\hline Observations & 50 & 50 & 50 & 50 \\
\hline
\end{tabular}

NOTE: * Denotes significance at the 10 percent level, ** at 5 percent. Absolute $t$-statistics are listed in parentheses and are based on White's heteroskedasticity-consistent standard errors. Area 1, size of government; Area 2, takings and discriminatory taxation; Area 3 , labor market freedom. See text for further description of the economic freedom indices.

economic freedom indices suggest that variation in economic freedom across the states generally decreased over time.

\section{RESULTS}

The empirical results for each period are shown in Tables 3 through 5 . All regressions included the economic freedom index at the state and local government level. In addition, all regressions included a set of eight regional dummy variables based on Census divisions to control for heterogeneity in growth rates across regions.
A brief summary of the findings for the other independent variables is warranted before we focus on the economic freedom results. ${ }^{20}$ The coefficients of the percentage change in the share of the population with a bachelor's degree are positive, but they are statistically significant only for the 2000-05 period (and in one specification for the 1990-2000 period). The coefficient of the percentage change in population density in the

\footnotetext{
${ }^{20}$ We also pooled the three periods to estimate a panel data model. The coefficient estimates from this model were roughly the average of the coefficients estimates from the three separate models. The results from the panel estimation are available on request.
} 


\section{Table 4}

\section{State and Local Economic Freedom and State Employment Growth (1990-2000)}

\begin{tabular}{|c|c|c|c|c|}
\hline \multirow[b]{2}{*}{ Variable } & \multicolumn{4}{|c|}{$\begin{array}{l}\text { Dependent variable: } \\
\text { Percent change in state payroll employment (1990-2000) }\end{array}$} \\
\hline & (1) & (2) & (3) & (4) \\
\hline Economic freedom $_{1990}$ & $\begin{array}{l}4.459^{* *} \\
(2.57)\end{array}$ & & & \\
\hline Economic freedom $_{1990}$ (Area 1) & & $\begin{array}{l}3.270^{* *} \\
(2.10)\end{array}$ & & \\
\hline Economic freedom $_{1990}$ (Area 2) & & & $\begin{array}{l}2.187 \\
(1.26)\end{array}$ & \\
\hline Economic freedom $_{1990}$ (Area 3) & & & & $\begin{array}{l}4.421^{* *} \\
(2.75)\end{array}$ \\
\hline Percent $\Delta$ in bachelor's degree & $\begin{array}{c}0.652 \\
(1.43)\end{array}$ & $\begin{array}{l}0.456 \\
(1.08)\end{array}$ & $\begin{array}{c}0.524 \\
(1.11)\end{array}$ & $\begin{array}{l}0.768^{*} \\
(1.71)\end{array}$ \\
\hline Population density ${ }_{1990}$ & $\begin{array}{l}-0.016^{* *} \\
(2.60)\end{array}$ & $\begin{array}{l}-0.016^{* *} \\
(2.66)\end{array}$ & $\begin{array}{l}-0.016^{* *} \\
(2.52)\end{array}$ & $\begin{array}{l}-0.016^{* *} \\
(2.39)\end{array}$ \\
\hline Percent in services $_{1990}$ & $\begin{array}{l}1.383^{* *} \\
(2.15)\end{array}$ & $\begin{array}{l}1.541^{* *} \\
(2.41)\end{array}$ & $\begin{array}{l}1.532^{* *} \\
(2.30)\end{array}$ & $\begin{array}{l}1.205^{* *} \\
(1.71)\end{array}$ \\
\hline Percent in manufacturing 1990 & $\begin{array}{c}0.392 \\
(0.83)\end{array}$ & $\begin{array}{c}0.517 \\
(1.14)\end{array}$ & $\begin{array}{c}0.479 \\
(1.03)\end{array}$ & $\begin{array}{l}0.334 \\
(0.73)\end{array}$ \\
\hline Constant & $\begin{array}{c}-71.041^{* *} \\
(2.57)\end{array}$ & $\begin{array}{c}-70.004^{* *} \\
(2.55)\end{array}$ & $\begin{array}{c}-60.517^{* *} \\
(2.11)\end{array}$ & $\begin{array}{c}-61.834^{* *} \\
(2.26)\end{array}$ \\
\hline Regional dummy variables & Yes & Yes & Yes & Yes \\
\hline Adjusted $R^{2}$ & 0.619 & 0.611 & 0.580 & 0.627 \\
\hline Adjusted $R^{2}$ (omit Freedom Index) & 0.572 & 0.572 & 0.572 & 0.572 \\
\hline Observations & 50 & 50 & 50 & 50 \\
\hline
\end{tabular}

initial year is negative and significant for the 1980-90 and 1990-2000 periods. This finding corresponds to our prior hypothesis that states with higher agglomeration have lower future employment growth rates. The coefficients of the share of total employment in manufacturing are negative and significant for the 2000-05 period but are generally not significant for the two earlier periods. The coefficients of the share of total employment in services are positive and significant for the 1980-90 and 1990-2000 periods but not for 2000-05.

Our key variables of interest are the economic freedom indices. We first discuss the results regarding the effect of overall economic freedom on state employment growth (column 1 of Tables 3 through 5). In accordance with our hypothesis, the coefficient of the overall economic freedom index is positive and significant for all three periods. The results indicate that a one-unit increase in the economic freedom index (roughly equal to $1 \mathrm{SD}$ ) in the initial year of a period resulted in increased employment growth of 3.8 percentage points from 1980 to 1990, 4.5 percentage points from 1990 to 2000, and 1.4 percentage points from 2000 to 2005 . In terms of explaining the variation in state employment growth, a comparison of the adjusted $R^{2}$ from each of the 
Table 5

State and Local Economic Freedom and State Employment Growth (2000-05)

\begin{tabular}{|c|c|c|c|c|}
\hline \multirow[b]{2}{*}{ Variable } & \multicolumn{4}{|c|}{$\begin{array}{l}\text { Dependent variable: } \\
\text { Percent change in state payroll employment (2000-05) }\end{array}$} \\
\hline & (1) & (2) & (3) & (4) \\
\hline Economic freedom $_{2000}$ & $\begin{array}{l}1.351^{*} \\
(1.90)\end{array}$ & & & \\
\hline Economic freedom $_{2000}($ Area 1 ) & & $\begin{array}{l}0.937^{*} \\
(1.72)\end{array}$ & & \\
\hline Economic freedom $_{2000}$ (Area 2) & & & $\begin{array}{c}0.546 \\
(1.03)\end{array}$ & \\
\hline Economic freedom $_{2000}($ Area 3$)$ & & & & $\begin{array}{l}1.797^{* *} \\
(2.35)\end{array}$ \\
\hline Percent $\Delta$ in bachelor's degree & $\begin{array}{l}0.543^{* *} \\
(2.17)\end{array}$ & $\begin{array}{l}0.500^{*} \\
(1.96)\end{array}$ & $\begin{array}{l}0.467^{*} \\
(1.90)\end{array}$ & $\begin{array}{l}0.591^{* *} \\
(2.53)\end{array}$ \\
\hline Population density $_{2000}$ & $\begin{array}{c}-0.003 \\
(1.29)\end{array}$ & $\begin{array}{c}-0.003 \\
(1.38)\end{array}$ & $\begin{array}{c}-0.003 \\
(1.23)\end{array}$ & $\begin{array}{c}-0.003 \\
(1.45)\end{array}$ \\
\hline Percent in services $_{2000}$ & $\begin{array}{c}-0.064 \\
(0.36)\end{array}$ & $\begin{array}{c}-0.085 \\
(0.46)\end{array}$ & $\begin{array}{c}0.022 \\
(0.11)\end{array}$ & $\begin{array}{c}-0.095 \\
(0.52)\end{array}$ \\
\hline Percent in manufacturing ${ }_{2000}$ & $\begin{array}{l}-0.514^{* *} \\
(3.77)\end{array}$ & $\begin{array}{c}-0.533^{* *} \\
(3.96)\end{array}$ & $\begin{array}{c}-0.473^{* *} \\
(3.59)\end{array}$ & $\begin{array}{c}-0.501^{* *} \\
(3.46)\end{array}$ \\
\hline Constant & $\begin{array}{c}0.282 \\
(0.03)\end{array}$ & $\begin{array}{c}4.403 \\
(0.50)\end{array}$ & $\begin{array}{c}1.987 \\
(0.19)\end{array}$ & $\begin{array}{c}-0.949 \\
(0.11)\end{array}$ \\
\hline Regional dummy variables & Yes & Yes & Yes & Yes \\
\hline Adjusted $R^{2}$ & 0.573 & 0.570 & 0.544 & 0.595 \\
\hline Adjusted $R^{2}$ (omit Freedom Index) & 0.547 & 0.547 & 0.547 & 0.547 \\
\hline Observations & 50 & 50 & 50 & 50 \\
\hline
\end{tabular}

NOTE: ${ }^{*}$ Denotes significance at the 10 percent level, ${ }^{* *}$ at 5 percent. Absolute $t$-statistics are listed in parentheses and are based on White's heteroskedasticity-consistent standard errors. Area 1, size of government; Area 2, takings and discriminatory taxation; Area 3 , labor market freedom. See text for further description of the economic freedom indices.

reported models with the adjusted $R^{2}$ from unreported models that omit the economic freedom index (the last three rows of Tables 3 through 5) shows that the overall economic freedom index explains roughly 3 to 5 percent of the total variation in state employment growth in each period.

The results for the economic freedom indices for Areas 1, 2, and 3 are shown in columns 2 through 4 of Tables 3 through 5 , respectively. ${ }^{21}$ First, consider the economic freedom index for the size of government (Area 1). The coefficient of this index is positive and significant for all three periods, revealing that employment growth is higher in states with smaller state and local governments as a share of total output. The Area 1 freedom index coefficient is largest for the 1980-90 period, revealing that a one-unit change in the index resulted in a 5.7-percentage-point increase in state employment growth. A one-unit change in the index for the two remaining periods resulted in a 3.3-percentage-point increase (1990-2000)

\footnotetext{
${ }^{21}$ We initially included the three area economic freedom indices in a single regression equation. However, the high correlation among the area freedom indices (average $\rho \approx 0.65$ ) dramatically decreased the precision of the coefficients estimates and, in some cases, produced improbable results. Thus, despite the recognized potential for omitted variable bias, we chose to estimate separate regressions for each of the area economic freedom indices.
} 
and a 0.9-percentage-point increase (2000-05) in employment growth. Again comparing adjusted $R^{2}$ s, the inclusion of the Area 1 economic freedom index explains roughly 2 to 10 percent of the total variation in state employment growth.

The coefficient estimates for the Area 2 economic freedom indices (takings and discriminatory taxation), although positive, are not statistically significant in any period. Thus, relative differences in taxation across the states in the initial years do not influence future state employment growth.

One reason for this finding may be that the majority of taxes considered by the economic freedom index (see Table 1) are consumer-based taxes, and the taxes levied on businesses may be ultimately borne by consumers. Another explanation may be that the growth periods of 5 and 10 years considered in this paper are longer than the impact of tax changes on employment growth, as in Tomljanovich (2004), which showed that tax changes have only short-run impacts on economic growth (within 5 years).

The coefficient estimates on the economic freedom index for Area 3 (labor market freedom) are positive and statistically significant for the 19902000 and 2000-05 periods. A one-unit increase in labor market economic freedom increases employment growth by 4.4 percentage points and 1.8 percentage points for the 1990-2000 and 2000-05 periods, respectively, and the inclusion of the labor market freedom index explains about 5 percent of the total variation in state employment growth based on each adjusted $R^{2}$.

The magnitude of the coefficients is larger for Area 3 than for Areas 1 and 2 in the 1990-2000 and 2000-05 periods, thereby suggesting that in more recent years labor market freedom has had a greater impact on state employment growth than the size of government and taxation. This is an intuitive result since business formation and expansion is directly influenced by labor costs, which constitute a significant portion of a firm's total costs. Our finding agrees with that of Kreft and Sobel (2005), who find that, of the three area economic freedom indices, labor market freedom has the largest impact on the number of sole proprietorships across the states.

At this point, a summary of our empirical results regarding the impact of economic freedom on state employment growth is worthwhile. We find that overall economic freedom has a positive and statistically significant effect on future state employment growth for the three periods. In addition, state labor market policies have the greatest impact on state employment growth, and the size of state governments has some impact as well. There is no evidence that taxation has a significant impact on future state employment growth for the periods considered in this study. Overall, the various economic freedom indices explain roughly 3 to 5 percent of the total variation in state employment growth, on average. This finding, in addition to the significant coefficient estimates, suggests that, at least for our sample periods, economic freedom is a significant factor in state employment growth, but economic freedom explains a relatively small percentage of the across-state variation in state employment growth.

\section{The Economic Significance of Economic Freedom}

In this section we highlight the economic significance of the economic freedom coefficient estimates by examining employment growth for the 10 states with the lowest economic freedom rankings for the initial year of each study period. Specifically, for these 10 states, we ask what state employment growth would have been if each state had an economic freedom index equal to the average U.S. state freedom index (see Table 2).

To answer this question, we first use the previous regression estimates (column 1 of Tables 3 through 5) to predict employment growth using each state's actual level of economic freedom. Next, we predict the state's employment growth using the mean level of economic freedom across the states and then we compare the two predictions of employment growth. Finally, we use the predicted level of employment in the initial year for each period to assess the increase in state employment for each period. One caveat of this prediction exercise is that we assume the effect of economic freedom on employment growth is the same for each state-that is, the estimated coefficients in column 1 of Tables 3 through 5 reflect the freedom-employment relationship in each state. 


\section{Garrett and Rhine}

Let us consider some findings shown in Table 6. ${ }^{22}$ Employment growth from 1980 to 1990 in New York would have been over 7 percentage points higher (column 3 vs. column 2) if its level of economic freedom (5.00) had equaled the U.S. state average (7.05). This translates into over 550,000 jobs (column 4). For Montana, the state with the lowest level of economic freedom in 1990, employment growth would have been 6.5 percentage points higher (about 19,300 jobs) if its level of economic freedom had equaled the U.S. state average. Finally, for the 2000-05 period, employment growth in Vermont would have been positive ( 0.7 percent, 2,900 jobs) if its economic freedom had equaled the U.S. state average.

In sum, comparing predicted employment growth based on the actual economic freedom index with the average U.S. state freedom index reveals that, on average across the 10 states, the states with the lowest level of economic freedom would have experienced employment growth roughly 5 percentage points higher over each 10-year period if the states had economic freedom equal to the U.S. state average. Employment growth would have been about 1.3 percentage points higher, on average, over the 2000-05 period.

\section{National and State Economic Freedom Indices}

The previous analysis considered economic freedom at the state and local government levels. In this section, we consider how economic freedom at the national, state, and local levels of government (i.e., "total government") influences state employment growth. The three areas and subcomponents for the "total government" economic freedom index are identical to those used for the state and local government freedom index (see Table 1), except the total government area indices also incorporate federal expenditures, tax

\footnotetext{
${ }^{22}$ Another caveat is that, because the economic freedom index is a relative index, in reality the economic freedom index for one state cannot change without changing the index for all other states. Thus, a state cannot simply move to the mean economic freedom level because most likely the mean level of economic freedom will change. Nevertheless, the exercise does reveal how much higher employment growth would have been if the low-freedom states had an economic freedom index equal to the mean of all U.S. states.
}

collections, employment, and minimum wage legislation. ${ }^{23}$ We reestimated all regressions in Tables 3 through 5 using the total government economic freedom indices in Karabegovic and McMahon (2008). The coefficients of the total government economic freedom indices can be compared with the state and local government economic freedom coefficients to assess the marginal effect of national government policies on state employment growth. For the sake of brevity, Table 7 presents only the coefficient estimates for the economic freedom indices. ${ }^{24}$

The results in Table 7 indicate that economic freedom at the total government level generally has no impact on state employment growth. The majority of the coefficients of economic freedom, although positive, are statistically insignificant. In only 3 of the 12 specifications is the effect of the freedom index statistically significant. These results, compared with the earlier results, generally suggest that relative differences in state and local government policy influence state employment growth, whereas relative differences in total government policies do not have a significant influence on state employment growth.

The one clear exception is labor market policies. The coefficient for Area 3 (labor market freedom) is significant for the 1990-2000 and 2000-05 periods, as is the overall index for 1990 to 2000. The coefficients of labor market freedom are greater than those obtained with state-level labor market freedom indices, thus indicating the cumulative increase in employment growth as a result of considering national-level labor market policies in addition to state-level policies (6.7 vs. 4.4 for 1990-2000 and 2.4 vs. 1.8 for 2000-05). In addition, the relative increase in the size of the coefficients for total government labor market policies compared with state-level policies is less than the size of the coefficients when state-level labor market policies are considered. This indicates that state-level labor market policies influence state employment growth more than national-level labor market policies.

\footnotetext{
${ }^{23}$ The average correlation between the state and local government freedom indices (the overall index and that of each of the three areas) and the total government indices is about 0.50 .

${ }^{24}$ Our complete results are available on request.
} 


\section{Table 6}

\section{Forecasted Employment Gains from Greater Economic Freedom:} The 10 States with the Lowest Economic Freedom

\begin{tabular}{|c|c|c|c|c|}
\hline \multirow[b]{2}{*}{ State } & \multirow[b]{2}{*}{ Freedom index } & \multirow{2}{*}{$\begin{array}{c}\text { (2) } \\
\text { Predicted } \\
\text { employment } \\
\text { growth }(\%)\end{array}$} & \multirow{2}{*}{$\begin{array}{c}\text { (3) } \\
\text { Predicted } \\
\text { employment growth } \\
\text { at freedom mean }(\%)\end{array}$} & \multirow{2}{*}{$\begin{array}{c}\text { (4) } \\
\text { Increase in } \\
\text { employment } \\
\text { at freedom mean }\end{array}$} \\
\hline & & & & \\
\hline \multicolumn{5}{|c|}{ 1980-90: Freedom score 1980} \\
\hline New York & 5.00 & 23.17 & 30.90 & 557,240 \\
\hline Michigan & 5.20 & 9.15 & 16.13 & 240,264 \\
\hline Rhode Island & 5.50 & 12.70 & 18.55 & 23,275 \\
\hline Maine & 5.70 & 23.75 & 28.84 & 21,294 \\
\hline West Virginia & 5.70 & 8.31 & 13.41 & 32,909 \\
\hline Oregon & 5.80 & 28.16 & 32.88 & 49,298 \\
\hline Vermont & 5.80 & 26.55 & 31.27 & 9,435 \\
\hline Hawaii & 6.00 & 27.80 & 31.76 & 16,014 \\
\hline Minnesota & 6.00 & 13.24 & 17.20 & 76,162 \\
\hline California & 6.10 & 36.17 & 39.76 & 353,297 \\
\hline \multicolumn{5}{|c|}{ 1990-2000: Freedom score 1990} \\
\hline Montana & 5.60 & 37.29 & 43.80 & 19,335 \\
\hline New York & 5.70 & 9.00 & 15.06 & 498,117 \\
\hline West Virginia & 5.80 & 12.48 & 18.09 & 35,396 \\
\hline Michigan & 5.90 & 17.01 & 22.18 & 204,104 \\
\hline Maine & 6.10 & 12.65 & 16.93 & 22,901 \\
\hline North Dakota & 6.20 & 16.74 & 20.58 & 10,200 \\
\hline Minnesota & 6.30 & 23.40 & 26.79 & 72,386 \\
\hline Oregon & 6.30 & 25.85 & 29.24 & 42,564 \\
\hline Rhode Island & 6.30 & 1.97 & 5.35 & 15,385 \\
\hline Washington & 6.30 & 24.62 & 28.01 & 72,623 \\
\hline \multicolumn{5}{|c|}{ 2000-05: Freedom score 2000} \\
\hline West Virginia & 5.50 & 1.33 & 3.37 & 15,014 \\
\hline Alaska & 5.80 & 7.90 & 9.53 & 4,643 \\
\hline Maine & 5.80 & 1.92 & 3.55 & 9,857 \\
\hline Rhode Island & 5.90 & -0.02 & 1.48 & 7,153 \\
\hline New York & 6.00 & 2.23 & 3.59 & 117,866 \\
\hline Hawaii & 6.10 & 10.31 & 11.54 & 6,774 \\
\hline Montana & 6.10 & 9.68 & 10.91 & 4,807 \\
\hline New Mexico & 6.20 & 6.90 & 8.00 & 8,153 \\
\hline Vermont & 6.30 & -0.27 & 0.69 & 2,868 \\
\hline California & 6.40 & 3.44 & 4.26 & 119,397 \\
\hline
\end{tabular}

NOTE: Column 2 contains the state-specific predicted values from the first regression specification in Tables 3 through 5 . Column 3 lists the state-specific predicted values from the first regression specification in Tables 3 through 5 using the mean value of economic freedom (state and local government only): 7.05 for 1980, 7.06 for 1990, and 7.01 for 2000. The data in column 4 were computed using 1980, 1990, and 2000 employment levels. 
Table 7

Total Government Economic Freedom and State Employment Growth

\begin{tabular}{|c|c|c|c|c|}
\hline \multirow[b]{2}{*}{ Variable } & \multicolumn{4}{|c|}{$\begin{array}{l}\text { Dependent variable: } \\
\text { Percent change in state payroll employment }\end{array}$} \\
\hline & (1) & $(2)$ & (3) & (4) \\
\hline \multicolumn{5}{|l|}{$1980-90$} \\
\hline Economic freedom & $\begin{array}{r}1.963 \\
(0.44)\end{array}$ & & & \\
\hline Economic freedom (Area 1) & & $\begin{array}{r}2.850 \\
(1.01)\end{array}$ & & \\
\hline Economic freedom (Area 2) & & & $\begin{array}{c}-0.315 \\
(0.05)\end{array}$ & \\
\hline Economic freedom (Area 3) & & & & $\begin{array}{r}0.985 \\
(0.29)\end{array}$ \\
\hline
\end{tabular}

\section{0-2000}

Economic freedom $4.123^{*}$

(1.80)

$\begin{array}{ll}\text { Economic freedom (Area 1) } & 2.411\end{array}$

(1.42)

$\begin{array}{lr}\text { Economic freedom (Area 2) } & 1.933\end{array}$

$(0.87)$

$\begin{array}{lr}\text { Economic freedom (Area 3) } & 6.728^{* *}\end{array}$

(3.10)

\section{0-05}

Economic freedom

1.241

$(1.51)$

Economic freedom (Area 1)

0.783

(1.24)

Economic freedom (Area 2)

0.263

(0.38)

Economic freedom (Area 3)

NOTE: *Denotes significance at the 10 percent level, ${ }^{* *}$ at 5 percent. Absolute $t$-statistics are listed in parentheses and are based on White's heteroskedasticity-consistent standard errors. Area 1, size of government; Area 2, takings and discriminatory taxation; Area 3, labor market freedom. See text for further description of the economic freedom indices. Each regression contains the same variables as the state and local economic freedom regressions shown in Tables 3 through 5 . The full set of estimates is available on request.

We explored the interesting finding that economic freedom at the total government level does not explain state employment growth except in the case of labor market policies. A look at the raw data shows that, on average, the economic freedom indices at the total government level are generally smaller than those at the state and local levels and, more importantly, the indices have significantly smaller SDs. For example, the average 1990 state and local government freedom index is 7.06 and has an SD of 0.69, whereas the average 1990 total government freedom index is 7.02 with an SD of 0.52. Thus, across states there is much less variation in total government economic freedom 
than in state and local economic freedom. This does not imply, however, that total government economic freedom does not necessarily influence state employment growth in a single state, but rather that differences in state and local government policy, and not total government policy, explain a portion of the variation in employment growth across U.S. states.

\section{SUMMARY AND CONCLUSION}

Explaining differences in the economic growth and development of countries and regions around the world has been the focus of a wide body of research. Human capital, technology, trade specialization, and economic freedommeaning the protection of private property and private markets operating with minimal government interference-are generally considered the principal determinants of economic growth and development. A more recent line of research has attempted to explain economic growth and development across subnational jurisdictions as well. To date, however, empirical models of subnational economic growth have ignored the importance of economic freedom in explaining differences in the economic growth of subnational jurisdictions.

In this paper, we augmented previous models of subnational economic growth by considering the role of economic freedom in explaining differences in employment growth in U.S. states. We considered employment growth over three periods: 1980-90, 1990-2000, and 2000-05. For each period, we find that states with greater overall economic freedom have higher rates of employment growth. This finding supports the conjecture in earlier literature that the current size of state and local governments, defined broadly, is larger than optimal. Generally, we find that a one-unit increase in the economic freedom index (roughly equal to $1 \mathrm{SD}$ ) increases employment growth by 1 to 4 percentage points for our sample periods, depending on specification. In addition, roughly 2 to 5 percent of the variation in employment growth across the states is explained by economic freedom.
Further results suggest that labor market freedom and a smaller state government, which are two components of overall economic freedom, are important determinants of employment growth across U.S. states, with the former factor the more important. Different tax policies across states do not have a significant effect on state employment growth, however. We also provide the interesting result that, in most cases, differences in employment growth across states can be partly explained by state and local government policies, but not policies of all levels of government. We do find, however, that labor market freedom at the state and national levels is a significant determinant of state employment growth, and state-level labor market policies appear to be more influential than national-level policies. This finding serves as an important policy implication for officials concerned with increasing economic growth.

Of note, the limitations of our study also serve as areas for future research. First, our results regarding the impact of economic freedom on employment growth are specific to the three periods we studied. Although we would generally expect a positive relationship between employment growth and economic freedom, there is no reason to assume that the magnitudes of our coefficient estimates are not period specific. Future research could extend our work by considering different periods, as well as shorter and longer durations, such as 3 years or 20 years. Second, because economic freedom is measured as an index, it is somewhat difficult to precisely implement policy based on our results given that the index is an aggregate of 10 government policy variables. The specific effect of each policy variable on the economic freedom index is unclear. Rather than considering only the overall freedom index and the index for each of the three components (size of government, taxation, labor market freedom), future research might implement a freedom index for each of the 10 government policy variables. 


\section{Garrett and Rhine}

\section{REFERENCES}

Ashby, Nathan J. and Sobel, Russell S. "Income Inequality and Economic Freedom in the U.S. States." Public Choice, March 2008, 134(3-4), pp. 329-46.

Auerbach, Alan J. and Gale, William G. "Activist Fiscal Policy to Stabilize Economic Activity.” NBER Working Paper No. 15407, National Bureau of Economic Research, October 2009.

Barro, Robert J. Determinants of Economic Growth: A Cross-Country Empirical Study (Lionel Robbins Lectures). Cambridge, MA: MIT Press, 1997.

Barro, Robert J. “Human Capital and Growth.” American Economic Review, May 2001, 91(2), pp. 12-17.

Barro, Robert J. and Sala-i-Martin, Xavier. Economic Growth. Second Edition. Cambridge, MA: MIT Press, 2004.

Billger, Sherrilyn M. and Goel, Rajeev K. "Do Existing Corruption Levels Matter in Controlling Corruption?” Journal of Development Economics, November 2009, 90(2), pp. 299-305.

Blankenau, William F. and Simpson, Nicole B. "Public Education Expenditures and Growth.” Journal of Development Economics, April 2004, 73(2), pp. 583-605.

Blumenthal, Pamela; Wolman, Harold L. and Hill, Edward. "Understanding the Economic Performance of Metropolitan Areas in the United States.” Urban Studies, March 2009, 46(3), pp. 605-27.

Carlino, Gerald and Mills, Leonard. "Convergence and the U.S. States: A Time-Series Analysis.” Journal of Regional Science, November 1996, 36(4), pp. 597-616.

Chatterjee, Santanu and Turnovsky, Stephen J. "Foreign Aid and Economic Growth: The Role of Flexible Labor Supply.” Journal of Development Economics, September 2007, 84(1), pp. 507-33.

Cole, Julio H. "The Contribution of Economic Freedom to World Economic Growth, 1980-99." Cato Journal, Fall 2003, 23(2), pp. 189-98; www.cato.org/pubs/journal/cj23n2/cj23n2-3.pdf.

Crain, W. Mark and Lee, Katherine J. "Economic Growth Regressions for the American States: A Sensitivity Analysis.” Economic Inquiry, April 1999, 37(2), pp. 242-57.

Daveri, Francesco and Tabellini, Guido. "Unemployment, Growth, and Taxation in Industrial Countries." Economic Policy: A European Forum, April 2000, 15(30), pp. 47-88.

Dawson, John W. "Institutions, Investment, and Growth: New Cross-Country and Panel Data Evidence." Economic Inquiry, October 1998, 36(4), pp. 603-19.

Durlauf, Steven N. "Manifesto for a Growth Econometrics." Journal of Econometrics, January 2001, 100(1), pp. 65-69.

Dye, Thomas R. “Taxing, Spending, and Economic Growth in the American States.” Journal of Politics, November 1980, 42(4), pp. 1085-107.

Elhorst, Paul J. "The Mystery of Regional Unemployment Differentials: Theoretical and Empirical Explanations." Journal of Economic Surveys, December 2003, 17(5), pp. 709-48. 
Esposto, Alfredo G. and Zaleski, Peter A. "Economic Freedom and the Quality of Life: An Empirical Analysis." Constitutional Political Economy, June 1999, 10(2), pp. 185-97.

Garrett, Thomas A.; Wagner, Gary A. and Wheelock, David C. "Regional Disparities in the Spatial Correlation of State Income Growth, 1977-2002.” Annals of Regional Science, September 2007, 41(3), pp. 601-18.

Gwartney, James D. “Institutions, Economic Freedom, and Cross-Country Differences in Performance.” Southern Economic Journal, April 2009, 75(4), pp. 937-56.

Gwartney, James D. and Lawson, Robert. Economic Freedom of the World: 2009 Annual Report. Vancouver, BC: Economic Freedom Network (Fraser Institute), 2009.

Hanson, John R. II. "Proxies in the New Political Economy: Caveat Emptor.” Economic Inquiry, October 2003, 41(4), pp. 639-46.

Haughwout, Andrew F. "State Infrastructure and the Geography of Employment.” Growth and Change, September 1999, 30(4), pp. 549-67.

Heckelman, Jac C. "Proxies for Economic Freedom: A Critique of the Hanson Critique.” Southern Economic Journal, October 2005, 72(2), pp. 492-501.

Karabegovic, Amela and McMahon, Fred. Economic Freedom of North America: 2008 Annual Report (Canadian Edition). Vancouver, BC: Fraser Institute, 2008.

Kreft, Steven F. and Sobel, Russell S. "Public Policy, Entrepreneurship, and Economic Freedom." Cato Journal, Fall 2005, 25(3), pp. 595-616; www.cato.org/pubs/journal/cj25n3/cj25n3-15.pdf.

Melkumian, Arsen V. “A Gravity Model of Legal Migration to the United States.” Working paper, Western Illinois University, 2004.

Mitchell, Daniel J. “The Impact of Government Spending on Economic Growth.” Executive Summary Backgrounder, No. 1831, March 2005; www.heritage.org/research/reports/2005/03/the-impact-of-government-spending-on-economic-growth.

Nickell, Stephen; Nunziata, Luca and Ochel, Wolfgang. "Unemployment in the OECD Since the 1960s: What Do We Know?” Economic Journal, January 2005, 115(500), pp. 1-27; www.res.org.uk/economic/freearticles/january05.pdf.

Nistor, Adela. "Assessing the Effectiveness of Human Capital Investments on the Regional Unemployment Rate in the United States: 1990 and 2000.” International Regional Science Review, January 2009, 32(1), pp. 65-91.

Norton, Seth W. "Poverty, Property Rights and Human Well-Being: A Cross-National Study.” Cato Journal, Fall 1998, 18(2), pp. 233-45.

Ovaska, Tomi and Sobel, Russell S. "Entrepreneurship in Post-Socialist Economies.” Journal of Private Enterprise, Fall 2005, 21(1), pp. 8-28.

Powell, Benjamin. "Economic Freedom and Growth: The Case of the Celtic Tiger." Cato Journal, Winter 2003, 22(3), pp. 431-48; www.cato.org/pubs/journal/cj22n3/cj22n3-3.pdf.

Puga, Diego. “The Magnitude and Causes of Agglomeration Economies.” Journal of Regional Science, February 2010, 50(1), pp. 203-19. 


\section{Garrett and Rhine}

Quah, Danny. "Empirical Cross-Section Dynamics in Economic Growth.” European Economic Review, April 1993, 37(2-3), pp. 426-34.

Quan, Nguyen T. and Beck, John H. "Public Education Expenditures and State Economic Growth: Northeast and Sunbelt Regions.” Southern Economic Journal, October 1987, 54(2), pp. 361-76.

Sturm, Jan-Egbert and De Haan, Jakob. "How Robust Is the Relationship between Economic Freedom and Economic Growth?” Applied Economics, June 2001, 33(7), pp. 839-44.

Tomljanovich, Marc. “The Role of State Fiscal Policy in State Economic Growth.” Contemporary Economic Policy, July 2004, 22(3), pp. 318-30.

Wasylenko, Michael and McGuire, Therese. "Jobs and Taxes: The Effect of Business Climate on States' Employment Growth Rates.” National Tax Journal, December 1985, 38(4), pp. 497-511.

Webber, Don J.; White, Paul and Allen, David O. "Income Convergence across U.S. States: An Analysis Using Measures of Concordance and Discordance.” Journal of Regional Science, August 2005, 45(3), pp. 565-89. 